\title{
Perancangan Kapasitas Produksi Produk Electronic Control Unit (Ecu)
}

\author{
Oktavia Sunny ${ }^{1}$ dan Anastasia Lidya Maukar ${ }^{2}$, Ineu Widaningsih Sosodoro ${ }^{3}$ \\ 1,2,3) Jurusan Teknik Industri, Fakultas Teknik President University \\ Jl. Ki Hajar Dewantara \\ Kota Jababeka,Cikarang, Bekasi - Indonesia 17550 \\ Email: oktavia.sunny@yahoo.co.id, almaukar@gmail.com, inesosodoro@yahoo.co.id
}

\begin{abstract}
Abstrak
Permintaan ekspor untuk produk Electoric Control Unit (ECU) yang terus meningkat kurang lebih 25\% pada Desember 2014 mnejadikan perusahaan harus meninjau ulang kapasitas produksinya. Berdasarkan data kapasitas produksi saat ini, diketahui cycle time proses sebesar 64,9 detik sedangkan takt time yang diperlukan untuk memenuhi permintaan konsumen adalah sebesar 39,4 detik untuk lini produksi pertama. Dengan waktu kerja yang dimiliki termasuk didalamnya jam kerja lembur, kapasitas lini pertama ini tidak dapat memenuhi permintaan produksi. Pengukuran kerja dilakukan untuk mendapatkan data waktu aktual untuk dilakukan perhitungan kapasitas. Man-machine chart salah satu tool yang yang digunakan untuk mengetahui kapasitas lini produksi dengan jumlah mesin dan pekerja saat ini. Untuk dapat memenuhi permintaan produksi dilakukan perancangan kapasitas dengan 2 usulan perbaikan, yaitu: menambah waktu kerja sebanyak 1 shif untuk lini produksi pertama atau menyeimbangkan waktu kerja antar lini. Dengan memperhitungkan hasil yang didapat dan biaya yang dikeluarkan maka usulan untuk penyeimbangan waktu kerja antar lini menjadi lebih efektif untuk dilakukan.
\end{abstract}

Kata kunci: pengukuran kerja, man machine chart, kapasitas produksi, Takt time, cycle time

\begin{abstract}
The export demand for Electoric Control Unit (ECU) products, which continued to increase by approximately $25 \%$ in December 2014, made the company have to review its production capacity. Based on current production capacity data, it is known that the process cycle time is 64.9 seconds while the takt time needed to meet consumer demand is 39.4 seconds for the first production line. With working time included in working hours overtime, this first-line capacity cannot meet production demands. Work measurement is done to get actual time data for capacity calculation. Man machine chart is one of the tools used to determine the production line capacity with the current number of machines and workers. To be able to fulfill the production demand, a capacity design with 2 proposed improvements is carried out, namely: adding a working time of one shift for the first production line or balancing work time between lines. By calculating the results obtained and the costs incurred, the proposal for balancing work time between lines becomes more effective to do.
\end{abstract}

Keywords: work measurement, man machine chart, production capacity, Takt time, cycle time

\section{Pendahuluan}

PT. XYZ Indonesia yang merupakan salah satu perusahaan manufaktur yang bergerak dalam bidang otomotif. Pasar dari PT. XYZ adalah perusahaan otomotif lokal, ekspor dan dealer. Oleh karena itu, perusahaan ini juga ikut merasakan adanya peningkatan permintaan ekspor. Permintaan ekspor untuk produk Electoric Control Unit (ECU) di bulan Desember 2014 meningkat kurang lebih 25\% dari bulanbulan sebelumnya.

Permintaan yang semkain meningkat harus diimbangi juga dengan peningkatan kapasitas produksi. Jika ada peningkatan permintaan signifikans, perlu dilakukan peninjauan ulang mengenai kapasitas produksi yang dapat dihasilkan oleh perusahaan. Peninjauan ulang pada lini produksi terkait dengan jumlah operator dan mesin yang ada saat. Perencanaan dan pengemdalian kapasitas berkaitan 
pemenuhan permintaan produksi dan bagaimana permintaan tersebut dapat terpenuhi dengan baik (Aarabi, dan Hasanian, 2014).

Perhitungan jam kerja yang dibutuhkan untuk memenuhi permintaan produksi menjadi sangat penting untuk memastikan apakah jam kerja yang tersedia sudah mencukupi. Jika jam kerja yang dibutuhkan melebihi dari jam kerja tersedia, maka perusahaan tidak dapat memenuhi permintaan produksi dari konsumen. Hal ini akan membuat citra buruk bagi perusahaan itu sendiri dan memungkinkan konsumen berpindah ke perusahaan lain.

Saat ini, PT. XYZ Indonesia memiliki tiga lini untuk memproduksi ECU. Dari hasil observasi awal dikethaui bahwa lini perakitan pertama memiliki cycle time proses sebesar 64,9 detik sedangkan Takt time yang diperlukan untuk memenuhi permintaan konsumen adalah sebesar 39,4 detik untuk produk ekspor. Takt time menentukan hasil/output dari produksi untuk memenuhi permintaan pelanggan dan mensinkronisasi semua proses produksi dari awal sampai akhir (Sabadka, Molnár, Fedorko, and Jachowicz, 2017). Oleh karena itu, dengan cycle time yang lebih besar dari Takt time maka dapat dikatakan bahwa kapasitas lini produksi tidak dapat memenuhi permintaan produksi dengan menggunakan jam kerja normal.

Tujuan penelitian ini adalah mengetahui bagaimana kapasitas lini pertama saat ini dan melakukan perancangan kapasitas produksi untuk memenuhi permintaan konsumen jika diperlukan. Oleh karena itu, akan dilakukan penelitian menggunakan man-machine chart untuk mengetahui keseimbangan antara mesin dan pekerja sehingga diketahui kapasitas produksi saat ini. Setelah mengetahui kapasitas produksi, maka dilakukan perancangan kapasitas produksi untuk dapat memenuhi permintaan produksi yang meningkat di bulan Desember 2014.

\section{Metode}

\subsection{Observasi Awal dan Analisis Kondisi Saat Ini}

Observasi awal dilakukan dengan mengamati lini produksi yang ada pada department produksi ECU. Berdasarkan data forecast pada bulan Desember, diketahui terjadi peningkatan produksi untuk produk ekspor. Dengan perhitungan waktu kerja yang diperlukan menggunakan waktu siklus yang ada, diketahui bahwa kapasitas produksi pada lini pertama tidak dapat memenuhi permintaan produksi. Waktu kerja yang diperlukan melebihi ketersediaan waktu yang sudah ditetapkan oleh perusahaan.

Data yang digunakan dalam penelitian ini adalah untuk September - Oktober 2014. Asumsi yang diterapkan pada penelitian ini adalah bahwa kemampuan operator antara satu dengan yang lainnya sama, tidak diperhitungkan adanya machine breakdown dan hari kerja normal pada setiap bulannya sebanyak 20 hari kerja.

\subsection{Pengumpulan Data}

Pengumpulan data dilakukan dengan melakukan observasi langsung mengenai proses produksi yang harus dilewati untuk membuat 1 unit ECU. Jumlah mesin dan operator juga dijelaskan pada tahap ini. Dengan jumlah mesin dan operator saat ini, dikumpulkan juga data untuk pembagian kerja per orang pada lini produksi pertama. Dilakukan juga time study dengan dengan menggunakan stopwatch untuk mendapatkan waktu proses pada tiap elemen kerja. Pengambilan data diambil 30 kali untuk setiap elemen kerja sebagai untuk mencari waktu operasi standar.

Sebelum menghitung waktu standar/baku, uji kecukupan data, kenormalan data, dan keseragaman data. Untuk uji kenormalan data dilakukan dengan bantuan software statistik. Sedangkan untuk uji kecukupan data dilakukan dengan menggunakan Persamaan (1).

$$
\begin{aligned}
& \quad n=\left(\frac{t s}{k x}\right)^{2} \\
& \text { Dimana, } \quad \mathrm{n}=\text { jumlah data yang diperlukan (siklus) } \\
& \mathrm{t}=\mathrm{t} \text {-table } \\
& \mathrm{k}=\text { standar error } \\
& \mathrm{x}=\text { nilai rata-rata atau mean }
\end{aligned}
$$

Jika nilai $\mathrm{n} \leq \mathrm{N}$, maka data dianggap cukup. Jika $\mathrm{n} \geq \mathrm{N}$, maka data dianggap tidak cukup dan perlu dilakukan penambahan data. 
Pada penelitian ini, tingkat keyakinan yang digunakan untuk menghitung kecukupan data adalah 99\% dan derajat ketelitian sebesar $10 \%$.

Sedangkan untuk uji keregaman data dilakukan perhitungan dengan menggunakan Persamaan (2).

$$
B K A=x+Z \text {. ( } \sigma x) \text { dan } B K B=x-Z .(\sigma x)
$$

Dimana $Z$ adalah bilangan konversi dari tingkat kepercayaan yang diinginkan ke distribusi normal sedangkan $x$ adalah nilai rata-rata. Dengan tingkat kepercayaan: $90 \%$, maka nilai $Z=1,65$.

Setelah melewati beberapa uji, dilakukan perhitungan swaktu normal dan waktu standar setiap elemen kerja/operasi. Dalam perhitungan waktu normal, dilakukan juga penentuan performance rating menggunakan The Westinghouse System yang mempertimbangkan empat faktor evaluasi, yaitu: kemampuan, usaha, kondisi lingkungan kerja dan konsistensi pekerjaan (Freivalds, 2008) dan didapatkan performance rating sebesar $112 \%$. Sedangkan allowance ditetapkan $10 \%$ untuk mendapatkan waktu standar.

\subsection{Langkah-langkah Perbaikan}

Setelah data terkumpul dari lini produksi, mesin-mesin yang harus dilewati untuk membuat satu unit ECU, dan waktu standar yang sudah diperhitungkan, maka dilakukan pembuatan peta kerja, yaitu man-machine chart. Peta kerja adalah suatu alat yang menggambarkan kegiatan kerja secara sistematis dan jelas. Peta kerja juga merupakan alat komunikasi secara luas dan sekaligus melalui peta-peta kerja ini kita bisa mendapatkan informasi-informasi yang diperlukan untuk memperbaiki suatu metode kerja. Salah satu peta kerja adalah Man-Machine Chart (MMC) sebagai salah satu alat yang dapat digunakan untuk menggambarkan koordinasi antara waktu bekerja dan waktu menganggur dari komuninasi antara pekerja dan mesin (Wignjosoebroto, 2008). Man-Machine Chart merupakan salah satu tipe dari Multi-Activity Chart, yaitu diagram proses yang menggunakan skala waktu yang umumnya digunakan studo pekerjaan (work study) dengan cara merekam kegiatan setiap subjek tertentu dibandingkan dengan yang lain pada satu grafik. Subjeknya bisa pekerja/operator, mesin atau peralatan (Rathod, Jadhav, dan Babar, 2016).

Langkah selanjutnya melakukan perhitungan TEC untuk mendapatkan biaya termurah dengan kapasitas maksimum. Selanjutnya, dilakukan analisis mengenai usulan perbaikan sehingga diketahui kapasitas maksimum lini produksi dengan menggunakan jumlah operator dan mesin yang ada saat ini.

Perhitungan jumlah mesin yang harus dilayani oleh tiap operator, menggunakan Persamaan (3):

Dimana:

$$
n=\frac{l+m}{l}
$$

$\mathrm{n} \quad=$ Jumlah mesin yang harus dilayani oleh operator.

l = Waktu loading dan unloading operator atau mesin.

$\mathrm{m} \quad=$ Jumlah waktu mesin.

Jika hasil n, didapatkan sebagai bilangan pecahan, maka Persamaan (4) dipakai.

Dimana:

$$
n \leq \frac{l+m}{l+w}
$$

$\mathrm{W} \quad=$ Waktu jalan operator dari 1 mesin ke mesin lain.

Hasil perhitungan menggunakan Persamaan (4) didapatkan $\mathrm{n}_{1}=$ pembulatan ke bawah dari $\mathrm{n}$ dan $\mathrm{n}_{2}=$ $\mathrm{n}_{1}+1$. Setelah mendapatkan $\mathrm{n}$, maka dilakukan perhitungan total expected cost per unit (TEC) dengan menggunakan Persamaan (5) atau Persamaan (6).

$$
\begin{gathered}
T E C_{n_{1}}=\frac{(l+m)\left(K_{1}+n_{1} x K_{2}\right)}{n_{1}} \\
T E C_{n_{2}}=(l+w)+\left(K_{1}+n_{2} x K_{2}\right)
\end{gathered}
$$

Dimana:

TEC $=$ Total expected cost per unit.

$\mathrm{K}_{1}$ = Biaya operator/unit.

$\mathrm{K}_{2}$ = Biaya mesin/unit

Perancangan kapasitas bertujuan agar kapasitas produksi dapat memenuhi permintaan konsumen. Berdasarkan langkah-langkah penelitian yang sudah dilakukan, dilakukan perbandingan kapasitas produksi saat ini dengan kapasitas produksi usulan untuk mengetahui apakah usulan perbaikan dapat dilakukan atau tidak. 


\section{Hasil dan Pembahasan}

\subsection{Kondisi Awal}

Pembuatan ECU memilik tiga lini dan hasil perhitungan pembebanan kerja dari masing-masing lini dapat dilihat pada Tabel 1.

Tabel 1. Waktu kerja yang dibutuhkan pada Desember 2014

\begin{tabular}{|c|c|c|c|}
\hline Item & Lini 1 & Lini 2 & Lini 3 \\
\hline Jumlah produksi (unit) & 14.584 & 14.541 & 9.463 \\
\hline Waktu siklus (detik) & 64,9 & 43,7 & 64,9 \\
\hline Waktu kerja yang diperlukan (jam) & 262.9 & 176.5 & 170.6 \\
\hline Ketersediaan waktu (jam) & 220 & 220 & 220 \\
\hline Utilisasi & $119,5 \%$ & $80,2 \%$ & $77,5 \%$ \\
\hline
\end{tabular}

Terdapat 3 operator pada lini pertama, dengan pembagian kerja sebagai berikut:

- Operator 1: PCB separating, data writing, in circuit checking dan $P C B$ and case asssembling.

- Operator 2: Stamping, resin pouring, resin hardening sampai dengan proses cooling.

- Operator 3: Function testing, stamp visual checking, appearance check dan packaging.

Pada operator 1 dan 3 merupakan proses mesin sedangkan operator 2 merupakan proses manual dan oven.

\subsection{Penentuan Waktu Standar}

Pengukuran kerja dilakukan secara observasi langsung pada stasiun kerja menggunakan metode jam henti. Pengambilan data diambil 30 kali secara berulang untuk setiap elemen kerja untuk operator 1 dan 3 . Hasil dari pengujian data adalah semua data lolos uji seperti terlihat pada Tabel 2.

Tabel 2. Hasil Pengujian Data

\begin{tabular}{|c|c|c|c|c|c|}
\hline Operator & Elemen Kerja & Uji Kecukupan & Uji Kenormalan & Uji Keseragaman & Hasil \\
\hline 1 & $1-49$ & $\sqrt{ }$ & $\sqrt{ }$ & $\sqrt{ }$ & Lolos \\
\hline 2 & $1-35$ & $\sqrt{ }$ & $\sqrt{ }$ & Lolos \\
\hline
\end{tabular}

Berdasarkan analisis yang sudah dilakukan didapatkan performance rating sebesar 1,12. Dengan toleransi sebesar $10 \%$ berdasarkan policy dari perusahaan, maka didapatkan waktu standar kerja. Hasil perhitungan waktu standar dari elemen kerja untuk operator 1 dan 3 seperti yang tercantum pada Tabel 3 dan Tabel 4.

Tabel 3. Elemen Kerja dan Waktu Standar Operator 1

\begin{tabular}{|c|c|c|c|c|c|}
\hline No & Elemen Kerja & $\begin{array}{c}\text { Waktu } \\
\text { rata-rata } \\
\text { (detik) }\end{array}$ & No & Elemen Kerja & $\begin{array}{c}\text { Waktu } \\
\text { rata-rata } \\
\text { (detik) }\end{array}$ \\
\hline 1 & Ambil circuit dari mesin $P C B$ Separating & 2.2 & 26 & Ambil case, transfer ke preheating & 2.1 \\
\hline 2 & Ambil sisa PCB, buang ke tempat sampah & 2.9 & 27 & Jalan ke mesin data writing & 3.5 \\
\hline 3 & $\begin{array}{l}\text { Ambil circuit dari box, setting ke mesin } \\
\text { PCB Separating }\end{array}$ & 8,5 & 28 & Buka mesin data writing & 4.6 \\
\hline 4 & Start mesin $P C B$ Separating & 1.2 & 29 & Ambil circuit dari mesin data writing & 1.4 \\
\hline 5 & Jalan ke mesin data writing & 1.2 & 30 & Setting circuit ke mesin data writing & 1.3 \\
\hline 6 & Buka mesin data writing & 4.0 & 31 & Tutup mesin data writing & 1.1 \\
\hline 7 & Ambil circuit dari mesin data writing & 1.2 & 32 & Start mesin data writing & 0.7 \\
\hline 8 & Setting circuit ke mesin data writing & 1.2 & 33 & Jalan ke mesin in circuit checking & 2.2 \\
\hline 9 & Tutup mesin data writing & 0.8 & 34 & Tunggu mesin & 1.2 \\
\hline 10 & Start mesin data writing & 0.7 & 35 & Buka mesin in circuit checking & 4.0 \\
\hline 11 & Jalan ke mesin in circuit checking & 1.9 & 36 & Stamping in circuit checking & 1.1 \\
\hline 12 & Tunggu mesin & 26.6 & 37 & $\begin{array}{l}\text { Ambil circuit dari mesin in circuit } \\
\text { checking }\end{array}$ & 1.7 \\
\hline 13 & Buka mesin in circuit checking & 1.1 & 38 & $\begin{array}{l}\text { Letakkan ke WIP mesin in circuit } \\
\text { checking }\end{array}$ & 1.2 \\
\hline 14 & Stamping in circuit checking & 3.6 & 39 & $\begin{array}{l}\text { Ambil circuit dari WIP mesin data } \\
\text { writing }\end{array}$ & 1.3 \\
\hline 15 & $\begin{array}{l}\text { Ambil circuit dari mesin in circuit } \\
\text { checking }\end{array}$ & 1.0 & 40 & $\begin{array}{l}\text { Setting circuit ke mesin in circuit } \\
\text { checking }\end{array}$ & 1.3 \\
\hline
\end{tabular}


Tabel 3. Elemen Kerja dan Waktu Standar Operator 1 (Lanjutan)

\begin{tabular}{|c|l|c|c|l|c|c|}
\hline No & \multicolumn{1}{|c|}{ Elemen Kerja } & $\begin{array}{c}\text { Waktu } \\
\text { rata-rata } \\
\text { (detik) }\end{array}$ & No & Elemen Kerja & $\begin{array}{c}\text { Waktu } \\
\text { rata-rata } \\
\text { (detik) }\end{array}$ \\
\hline 16 & Letakkan ke WIP mesin in circuit checking & 1.6 & 41 & Tutup mesin in circuit checking & 1.1 \\
\hline 17 & Ambil circuit dari WIP mesin data writing & 1.0 & 42 & Start mesin in circuit checking & 1.3 \\
\hline 18 & Setting circuit ke mesin in circuit checking & 1.1 & 43 & Jalan ke pos perakitan case & 2.2 \\
\hline 19 & Tutup mesin in circuit checking & 1.1 & 44 & $\begin{array}{l}\text { Ambil circuit dari WIP mesin in circuit } \\
\text { checking }\end{array}$ & 1.3 \\
\hline 20 & Start mesin in circuit checking & 1.0 & 45 & $\begin{array}{l}\text { Ambil case kemudian rakit case } \\
\text { dengan circuit }\end{array}$ & 3.1 \\
\hline 21 & Jalan ke pos perakitan case & 1.1 & 46 & Letakkan case assy ke jig stamp & 2.1 \\
\hline 22 & $\begin{array}{l}\text { Ambil circuit dari WIP mesin in circuit } \\
\text { checking }\end{array}$ & 1.9 & 47 & Stamping part number pada case & 2.1 \\
\hline 23 & $\begin{array}{l}\text { Ambil case kemudian rakit case dengan } \\
\text { circuit }\end{array}$ & 1.9 & 48 & Ambil case, transfer ke preheating & 4.2 \\
\hline 24 & Letakkan case assy ke jig stamp & 1.1 & 49 & Jalan ke mesin PCB Separating & 4.2 \\
\hline 25 & Stamping part number pada case & 2.8 & \multicolumn{2}{|l}{}
\end{tabular}

Tabel 4. Elemen Kerja dan Waktu Standar Operator 3

\begin{tabular}{|c|c|c|c|c|c|}
\hline No & Elemen Kerja & $\begin{array}{c}\text { Waktu } \\
\text { rata-rata } \\
\text { (detik) }\end{array}$ & No & Elemen Kerja & $\begin{array}{c}\text { Waktu } \\
\text { rata-rata } \\
\text { (detik) }\end{array}$ \\
\hline 1 & $\begin{array}{l}\text { Ambil produk dari mesin function } \\
\text { testing }\end{array}$ & 1 & 19 & Letakkan di WIP mesin function testing & 1.8 \\
\hline 2 & Letakkan di WIP mesin function testing & 1.8 & 20 & Stamping function testing case & 4.0 \\
\hline 3 & Stamping function testing case & 4 & 21 & Ambil produk dari WIP Cooling & 1.1 \\
\hline 4 & Ambil produk dari WIP Cooling & 1.1 & 22 & Setting di mesin function testing & 1.9 \\
\hline 5 & Setting di mesin function testing & 1.9 & 23 & Start mesin function testing & 0.6 \\
\hline 6 & Start mesin function testing & 0.6 & 24 & Setting produk pad jig stamp visual cek & 3.5 \\
\hline 7 & Setting produk pad jig stamp visual cek & 3.5 & 25 & Start mesin stamp visual cek & 0.3 \\
\hline 8 & Start mesin stamp visual cek & 0.9 & 26 & $\begin{array}{l}\text { Ambil dan letakkan produk pada jig } \\
\text { stamp tanggal }\end{array}$ & 2.5 \\
\hline 9 & $\begin{array}{l}\text { Ambil dan letakkan produk pada jig } \\
\text { stamp tanggal }\end{array}$ & 2.4 & 27 & Stamp tanggal pada case & 5.0 \\
\hline 10 & Stamp tanggal pada case & 5.0 & 28 & $\begin{array}{l}\text { Posisikan produk di bawah sinar } \\
\text { ultraviolet }\end{array}$ & 1.1 \\
\hline 11 & $\begin{array}{l}\text { Posisikan produk di bawah sinar } \\
\text { ultraviolet }\end{array}$ & 1.1 & 29 & Cek penampilan produk & 18.7 \\
\hline 12 & Cek penampilan produk & 18.7 & 30 & Beri tanda pada case & 2.5 \\
\hline 13 & Beri tanda pada case & 2.5 & 31 & Letakkan produk pada box & 2.6 \\
\hline 14 & Letakkan produk pada box & 2.6 & 32 & Scan kanban & 0.9 \\
\hline 15 & Scan kanban & 0.9 & 33 & $\begin{array}{l}\text { Ambil label, pasang kanban dan label } \\
\text { pad box }\end{array}$ & 0.4 \\
\hline 16 & $\begin{array}{l}\text { Ambil label, pasang kanban dan label } \\
\text { pad box }\end{array}$ & 0.4 & 34 & Jalan ke mesin function testing & 2.2 \\
\hline 17 & Jalan ke mesin function testing & 2.2 & 35 & Tunggu mesin & 29.1 \\
\hline 18 & $\begin{array}{l}\text { Ambil produk dari mesin function } \\
\text { testing }\end{array}$ & 1 & & & \\
\hline
\end{tabular}

\subsection{Analisis Kapasitas Lini Produksi Saat Ini}

Dengan menganalisis Man Machine Chart (MMC) seperti yang tercantum pada Lampiran, dapat diketahui:

- Operator 1 mengerjakan 4 mesin, yaitu mesin separating, data writing, in circuit checking (ICC) 1 dan ICC 2. Berdasarkan MMC, operator 1 memiliki proses menganggur sebesar 29,5 detik untuk menunggu mesin ICC. Proses dalam 1 siklusnya dapat menghasilkan 2 unit produk karena 1 circuit assy yang diproses pada pcb separating menghasilkan 2 unit. Selain itu, terdapat 2 mesin ICC. Total waktu siklus adalah 125,8 detik untuk 2 unit produk, sehingga waktu siklus per produk adalah 62,9 detik. 
- Operator 3 juga memiliki waktu menganggur sebesar 29,1 detik saat menunggu mesin function testing (FT). Operator 3 mengerjakan 3 jenis mesin, yaitu mesin FT 1, FT 2, dan stamp visual check. Pada lini produksi ECU, tedapat 2 mesin FT maka untuk 1 siklus operator 3 juga menghasilkan 2 unit produk. Total waktu siklus berdasarkan MMC pada gambar 5.4 adalah 129,8 detik untuk 2 unit produk, sehingga 1 unit produk membutuhkan waktu 64,9 detik.

Selanjutnya dilakukan perhitungan total expected cost (TEC) untuk mengetahui kapasitas optimal dari lini produksi menggunakan Persamaan (6) dan (7).

Tabel 5. Hasil Perhitungan TEC

\begin{tabular}{|c|c|c|c|}
\hline \multirow{2}{*}{ Operator 1 } & Item & $\mathrm{n} 1$ & $\mathrm{n} 2$ \\
\cline { 2 - 4 } & Jumlah mesin & 4 & 5 \\
\hline \multirow{2}{*}{ Operator 3 } & TEC & Rp. 1.201.953 & Rp. 48.853.948 \\
\cline { 2 - 4 } & TEC & 3 & 4 \\
\hline
\end{tabular}

Hasil TEC menggunakan $n_{1}$ lebih kecil dari $n_{2}$, maka kondisi jumlah mesin dan operator saat ini sudah dalam kondisi optimal.

\subsection{Usulan Perbaikan}

Dengan kondisi saat ini, total waktu produksi yang dibutuhkan adalah 262,9 jam untuk 1 bulan. Sedangkan, ketersediaan waktu produksi maksimal adalah 220 jam dengan rincian 160 jam waktu kerja normal dan 60 jam kerja waktu kerja lembur. Karena produksi ECU masih menggunakan 1 shift produksi, maka waktu kerja maksimal dalam 1 hari adalah 11 jam, dengan 8 jam kerja normal dan 3 jam kerja lembur. Oleh karena itu, total jam yang tidak dapat dicukupkan dengan waktu siklus/unit 64,9 detik adalah 42,9 jam atau setara dengan 2.380 unit.

\subsubsection{Penambahan Waktu Kerja Menjadi 2 Shift Produksi}

Salah satu usulan yang dapat dilakukan adalah dengan menambah waktu kerja menjadi 2 shift produksi. Untuk usulan ini, diperlukan penambahan operator, sehingga produksi dapat dikerjakan menjadi 2 shift. Dengan usulan ini, maka jam kerja produksi dapat bertambah sebesar 160 jam. Sehingga, total waktu kerja normal menjadi 320 jam. Dengan 320 jam, maka semua permintaan produksi di bulan Desember 2014 dapat dilakukan tanpa menambah jam kerja lembur dan tersedia jam kerja kosong sebanyak 57.1 jam untuk bulan Desember 2014. Jam kosong tersebut dapat membuat produksi sebanyak 3.167 unit.

Untuk melakukan usulan ini, diperlukan 3 operator untuk proses dan 1 pengawas untuk shift malam. Sehingga, total dibutuhkan 4 operator baru. Dengan perhitungan dengan biaya pekerja kontrak per tahun sebesar Rp. 45.760.000, maka biaya pekerja kontrak per bulan dapat dihitung dengan membagi biaya pekerja per tahun dengan 12 bulan. Sehingga biaya pekerja kontrak per bulan sebesar Rp. 3.813.333. Karena dibutuhkan 4 orang, sehingga biayanya menjadi: 4 orang $x$ Rp. $3.813 .333=$ Rp. 15.253.332.

\subsubsection{Menyeimbangkan Waktu Kerja Antar Lini}

Produksi ECU memiliki 3 lini produksi, dengan jam kerja yang berbeda-beda sesuai dengan jumlah produksi yang dijalankan. Ketiga lini produksi memiliki jumlah mesin dan operator yang sama. Untuk lini pertama dan ketiga memproduksi ECU tipe besar, sedangkan pada lini kedua untuk memproduksi ECU tipe kecil. Proses pembuatan untuk ECU tipe besar dan ECU tipe kecil adalah sama. Perbedaan hanya pada waktu mesin dikarenakan ukuran ECU yang berbeda. Dengan data pendukung tersebut, dapat dikatakan kemampuan operator untuk semua lini produksi adalah sama.

Tabel 6. Waktu Kerja Lini Produksi

\begin{tabular}{|l|c|c|c|}
\hline \multicolumn{1}{|c|}{ Item } & Lini 1 & Lini 2 & Lini 3 \\
\hline Waktu kerja yang diperlukan (jam) & 262,9 & 176,5 & 170,6 \\
\hline Waktu kerja maksimal yang tersedia (jam) & 220 & 220 & 220 \\
\hline Selisih waktu & $-42,9$ & 43,4 & 49,4 \\
\hline Utilisasi & $119,5 \%$ & $80,2 \%$ & $77,5 \%$ \\
\hline
\end{tabular}


Utilisasi lini 1 dan 3 masih dibawah 100\%, sehingga, kekurangan waktu pada lini pertama memungkinkan untuk dapat dialokasikan pada lini kedua atau ketiga. Beberapa perlengkapan yang harus dilengkapi, yaitu:

a. Mesin, sesuai dengan aliran proses produksi.

b. Jig, sesuai dengan bentuk circuit assy.

c. Program mesin, sesuai dengan nomor produk.

d. Pallet untuk proses resin potting.

Tabel 7. Perbandingan Lini 1,2 dan 3

\begin{tabular}{|c|c|c|c|c|}
\hline No & Item & Lini 1 & Lini 2 & Lini 3 \\
\hline 1 & Mesin & $\begin{array}{l}\text { - Data writing } \\
\text { - In circuit checking } \\
\text { - Preheating } \\
\text { - Resin pouring } \\
\text { - Resin hardening } \\
\text { - Cooling } \\
\text { - Function testing } \\
\text {-Stamp visual check }\end{array}$ & $\begin{array}{l}\text { - Data writing } \\
\text { - In circuit checking } \\
\text { - Preheating } \\
\text { - Resin pouring } \\
\text { - Resin hardening } \\
\text { - Cooling } \\
\text { - Function testing } \\
\text {-Stamp visual check }\end{array}$ & $\begin{array}{l}\text { - Data writing } \\
\text { - In circuit checking } \\
\text { - Preheating } \\
\text { - Resin pouring } \\
\text { - Resin hardening } \\
\text { - Cooling } \\
\text { - Function testing } \\
\text {-Stamp visual check }\end{array}$ \\
\hline 2 & Jig & Tipe besar & Tipe kecil & Tipe besar \\
\hline 3 & Program & Tersedia & Belum tersedia & Belum tersedia \\
\hline 4 & Pallet & Tipe besar & Tipe kecil & Tipe besar \\
\hline
\end{tabular}

Pertimbangan pemindahan loading produksi harus ditinjau kembali dari jig yang tersedia. Untuk lini kedua saat ini memproduksi ECU tipe kecil sehingga jig yang dimiliki hanya jig tipe kecil. Pemindahan loading produksi dari lini pertama ke lini kedua membutuhkan persiapan jig baru untuk tipe besar. Persiapan jig membutuhkan waktu cukup lama, yaitu 3 bulan. Lini ketiga saat ini sudah memiliki jig tipe besar karena memang memproduksi ECU tipe besar yang memiliki target market dealer. Sedangkan, penambahan program dilakukan oleh production engineering department. Setting program untuk 1 mesin membutuhkan waktu selama 10 menit. Pada lini ketiga terdapat 6 mesin, sehingga proses setting program dibutuhkan waktu selama 60 menit. Proses setting dapat dilakukan pada waktu istirahat sehingga tidak mengganggu jalannya produksi. Untuk melakukan perbaikan ini, diperlukan biaya lembur untuk operator 3 sebesar Rp.3.074.457.

\subsubsection{Analisis Perbandingan Usulan Perbaikan 1 dan 2}

Permintaan produksi dapat dipenuhi oleh kedua usulan perbaikan, sehingga tujuan penelitian dapat dipenuhi. Dengan pertimbangan biaya, maka usulan 2 yang lebih baik diimplementasikan. Keseimbangan beban kerja antar lini juga dapat menjadi lebih seimbang dengan melakukan usulan perbaikan 2 .

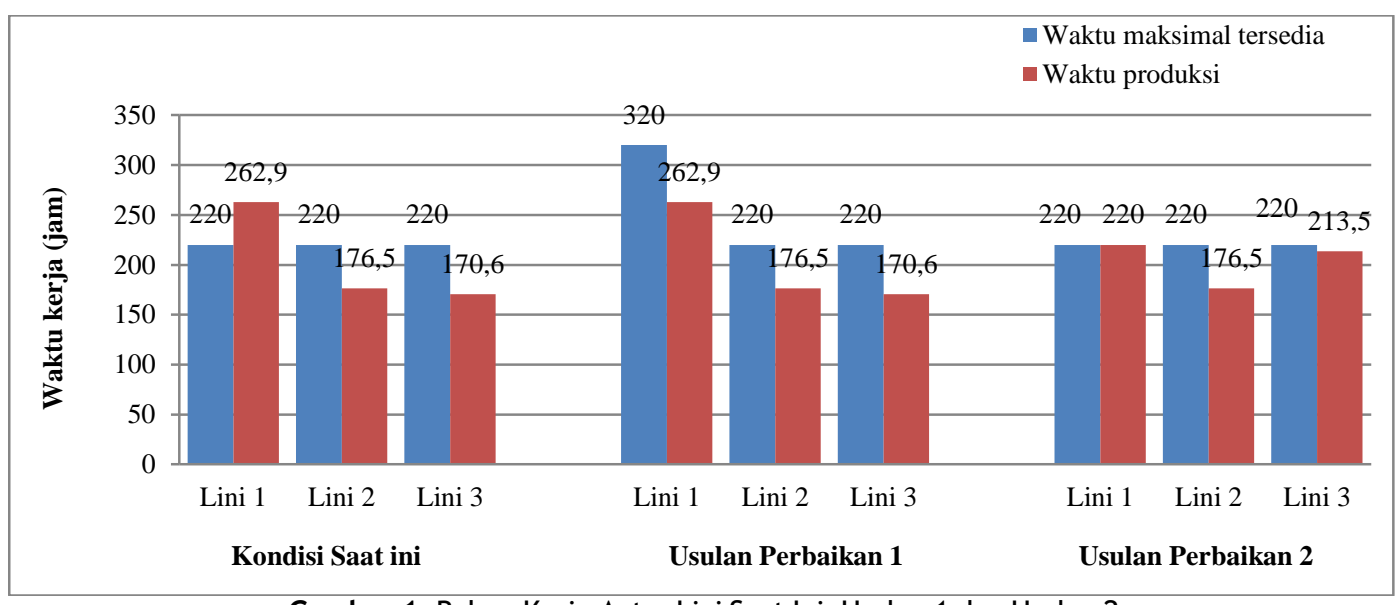

Gambar 1. Beban Kerja Antar Lini Saat Ini, Usulan 1 dan Usulan 2 


\subsection{Implementasi Usulan Perbaikan}

Usulan perbaikan yaitu penyeimbangan lini produksi dengan mengalokasikan sebagian pekerjaan lini pertama ke lini ketiga. Usulan perbaikan mulai diimplementasikan pada Januari 2015.

Jam kerja normal pada PT. XYZ dimulai dari 08:30 sampai dengan 16:30. Waktu tersebut sudah termasuk dengan waktu istirahat selama 1 jam, sehingga waktu kerja normal adalah 8 jam. Untuk lembur, dimulai dari jam 16:30 sampai dengan 20:00, waktu istirahat terdapat pada 16:30-16:40 dan 18:10-18:30, sehingga waktu lembur yang dapat digunakan untuk produksi adalah 3 jam. Total waktu kerja maksimal yang tersedia untuk 1 hari 1 shift adalah 11 jam. Hari kerja normal pada bulan Januari 2015 adalah 21 hari. Waktu kerja maksimal untuk lini ECU yang tersedia adalah 11 jam $\times 21$ hari = 231 jam/bulan.

Tabel 8. Beban Kerja Januari 2015

\begin{tabular}{|l|c|c|c|}
\hline \multicolumn{1}{|c|}{ Item } & Lini 1 & Lini 2 & Lini 3 \\
\hline Jumlah permintaan produksi/bulan (unit) & 14.728 & 15.012 & 9.565 \\
\hline Kapasitas produksi/jam (unit) & 55 & 82 & 55 \\
\hline Waktu kerja yang diperlukan (jam) & 267 & 183 & 173 \\
\hline Waktu kerja maksimal yang tersedia (jam) & 231 & 231 & 231 \\
\hline Selisih waktu & -36 & 48 & 58 \\
\hline
\end{tabular}

Pada Januari 2015, untuk lini pertama kekurangan waktu kerja selama 36 jam untuk membuat produk sesuai dengan permintaan konsumen. Berdasarkan usulan perbaikan, maka sebagian produksi pada lini 1 dialokasikan ke lini 3. Monitoring dilakukan selama 5-16 Januari 2015.

Tabel 9. Data Jumlah Produksi Lini 1 dan 3 (5-9 Januari 2015)

\begin{tabular}{|c|c|c|c|c|c|c|}
\hline \multirow{2}{*}{ Lini/Tanggal } & Senin & Selasa & Rabu & Kamis & Jumat & Jumlah rata-rata per hari \\
\cline { 2 - 5 } & 5-Jan & 6-Jan & 7-Jan & 8-Jan & 9-Jan & (unit) \\
\hline Jumlah Produksi Lini 1 & 604 & 598 & 603 & 598 & 586 & 598 \\
\hline Jumlah Produksi Lini 3 & 592 & 592 & 604 & 604 & 598 & 598 \\
\hline Total Produksi (unit) & 1196 & 1190 & 1208 & 1202 & 1184 & 1,196 \\
\hline
\end{tabular}

Tabel 10. Data Jumlah Produksi Lini 1 dan 3 (12-16 Januari 2015)

\begin{tabular}{|c|c|c|c|c|c|c|}
\hline \multirow{2}{*}{ Lini/Tanggal } & Senin & Selasa & Rabu & Kamis & Jumat & \multirow{2}{*}{$\begin{array}{c}\text { Jumlah rata-rata per } \\
\text { hari (unit) }\end{array}$} \\
\cline { 2 - 6 } & 12-Jan & 13-Jan & 14-Jan & 15-Jan & 16-Jan & 598 \\
\hline Jumlah Produksi Lini 1 & 598 & 604 & 604 & 600 & 596 & 598 \\
\hline Jumlah Produksi Lini 3 & 600 & 600 & 602 & 598 & 592 & 1,199 \\
\hline Total Produksi (unit) & 1198 & 1204 & 1206 & 1198 & 1187 & \\
\hline
\end{tabular}

Berikut hasil dari rata-rata sebagai berikut:

Rata-rata total produksi/hari tanggal 5-9 Januari : 1.196 unit

Rata-rata total produksi/hari tanggal 12-16 Januari : 1.199 unit

Rata-rata total produksi/hari tanggal 5-16 Januari : 1.197 unit

Jumlah permintaan produksi lini 1 dan 3 adalah 24.293/bulan atau 1.156 unit/hari. Oleh karena itu, kapasitas lini produksi dapat memenuhi permintaan produksi pada bulan Januari 2015 dengan pemenuhan 100\%.

\subsection{Analisis Implementasi Perbaikan}

Dengan melakukan implementasi mengalokasikan sebagian beban kerja lini pertama ke lini ketiga, maka beban pekerjaan antar lini dapat menjadi lebih seimbang. Penggunaan lini produksi pun menjadi lebih optimal, tidak hanya membebankan pada satu lini produksi.

Pada kondisi saat ini, beban kerja yang dapat diseimbangkan hanya pada lini 1 dan 3 karena perlengkapan produksi yang sudah tersedia. Terkait dengan permintaan produksi motor yang cepat berubah, maka akan lebih baik jika semua tipe ECU dapat diproses pada ketiga lini produksi, sehingga department produksi dapat menjadi lebih mudah untuk menyeimbangkan beban kerja antar lini. Kondisi mesin dan operator untuk ketiga lini sudah memadai, sehingga yang perlu dipersiapkan selanjutnya adalah jig, pallet dan program. 


\section{Simpulan}

Dengan jumlah operator dan mesin saat ini, waktu siklus untuk membuat satu unit produk ECU sebesar 64,9 detik. Dengan waktu siklus tersebut, total waktu produksi yang dibutuhkan adalah 262,9 jam, sedangkan waktu produksi yang tersedia adalah 220 jam dengan perincian 160 jam kerja normal dan 60 jam kerja lembur dalam waktu 20 hari kerja untuk satu bulan. Oleh karena itu, dengan kapasitas lini produksi pertama ini tidak dapat memenuhi permintaan konsumen karena kelebihan jam kerja produksi sebesar 42,9 jam atau setara dengan 2.380 unit.

Utilisasi dari lini kedua sebesar $80,2 \%$ sedangkan lini ketiga sebesar $77,5 \%$, sedangkan utilisasi lini pertama sebesar $119,5 \%$. Dengan mempertimbangkan perlengkapan yang diperlukan untuk membuat produk lini pertama yang sudah tersedia pada lini ketiga, maka untuk memenuhi permintaan konsumen, dilakukan penyeimbangan lini produksi dengan mengalokasikan sebagian pekerjaan dari lini pertama ke lini ketiga.

\section{Daftar Pustaka}

1. Aarabi, M, and Hasanian, S., 2014. Capacity planning and control: a review. International Journal of Scientific \& Engineering Research, Volume 5, Issue 8, pp. 975-984.

2. Freivalds, A. 2008. Niebel's Methods, Standards, and Work Design. $12^{\text {th }}$ Edition. New York: McGrow-Hill.

3. Wignjosoebroto, S., 2008. Ergonomi Studi Gerak dan Waktu - Teknik Analisis untuk Peningkatan Produktivitas Kerja Edisi Kedua, Surabaya: Guna Widya.

4. Rathod, A.S, Jadhav, R.G., and Babar, A.B., 2016. An Overview of Method Study and Study of Different Recording Techniques. International Journal of Science and Research, Vol. 5(8), pp. 1484-1491.

5. Sabadka, D., Molnár, V., Fedorko, G., and Jachowicz, T., 2017. Optimization of Production Processes Using the Yamazumi Method. Advances in Science and Technology Research Journal, Volume 11, Issue 4, pp. 175182. 


\section{Lampiran}

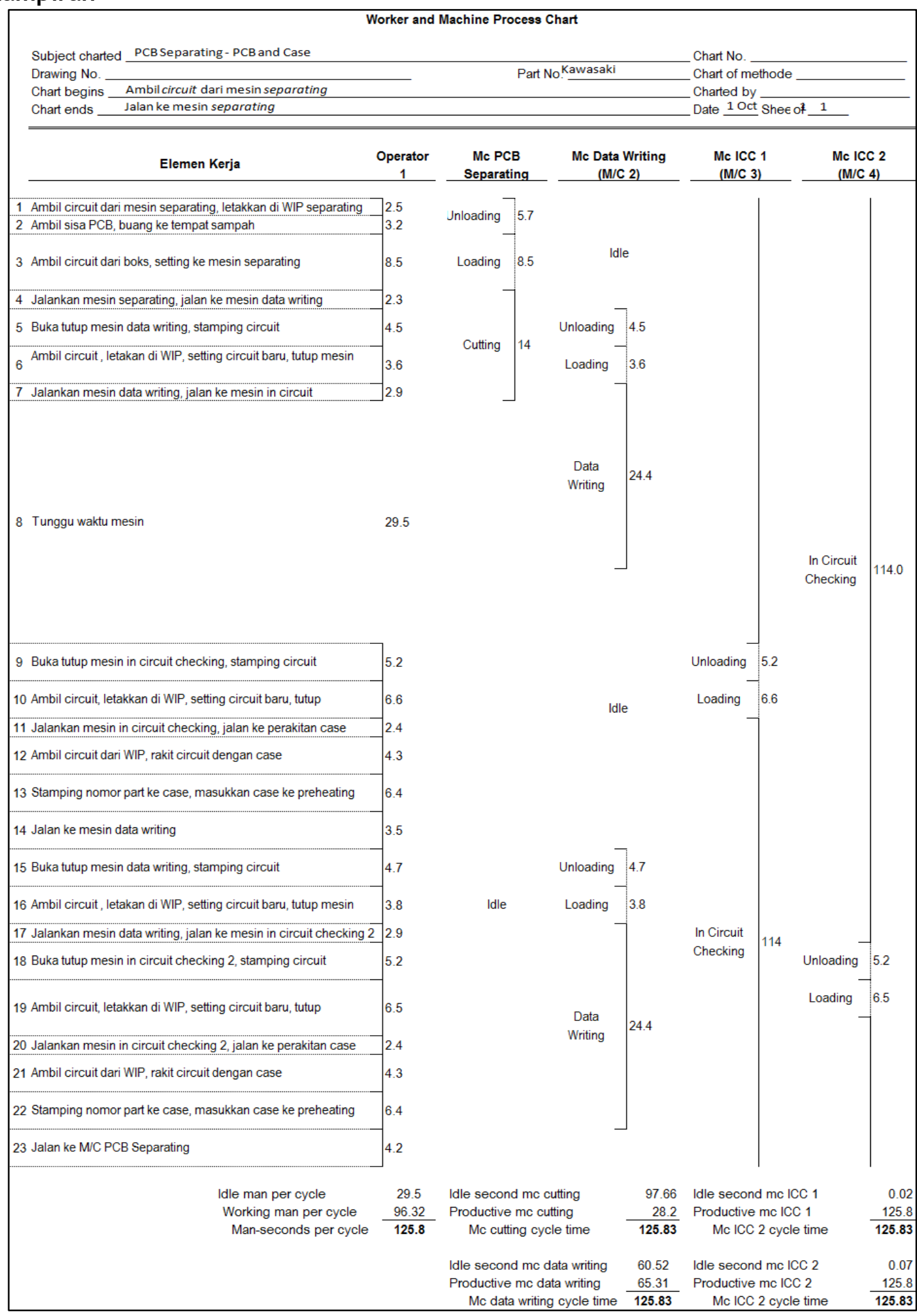

Man-Machine Chart dari Operator 1 
JIE, Vol. 4, No.1, March 2019: 53-65

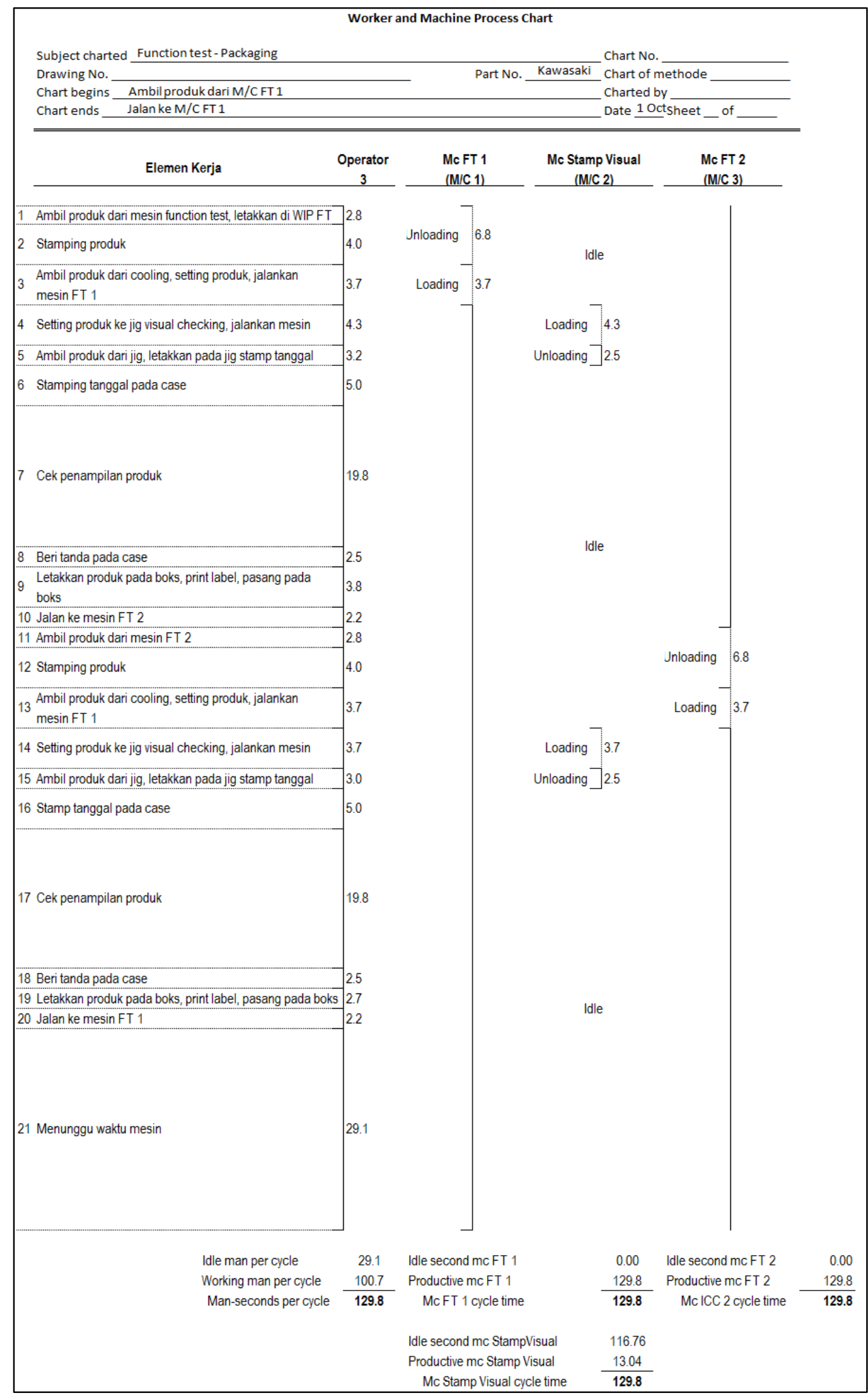

Man-Machine Chart dari Operator 3 